\title{
THE MUONG EPIC CYCLE OF 'THE BIRTH OF THE EARTH AND WATER': MAIN THEMES, MOTIFS, AND CULTURE HEROES
}

\author{
Nina Grigoreva \\ Department of Asian and African Studies \\ National Research University Higher School of Economics \\ Saint Petersburg, Russia \\ e-mail:ngrigoreva@hse.ru
}

\begin{abstract}
This article seeks to introduce into comparative folkloristics an epic tradition of the Muong, one of minority groups in northern Vietnam. More precisely, it deals with the epic cycle of 'The Birth of the Earth and Water', which represents an essential part of the Muong ritual narratives. This cycle was presumably created not later than the fifteenth century and was intended for practicing mourning rituals. Although in 2015 ritual narratives of the Muong were recognized as national intangible cultural heritage in Vietnam, the Muong epics have remained practically unknown and unexplored in Western scholarship.

The article discusses the most common epic themes, such as creation, man's origin and reproduction, acquisition of culture, and deeds and fights of the main culture heroes through a number of motifs represented in tales constituting the Muong epic cycle. Comparative analysis of these themes and motifs in global and regional perspectives reveals obvious parallels with their representations in the world folklore as well as some specific variations and local links.
\end{abstract}

Keywords: comparative analysis, culture hero, epic cycle, motif, the Muong, ritual narratives, theme, Vietnam

Research into universal archetypes and themes, classification of recurrent motifs as well as analysis of culture heroes and revealing common patterns in their representations became main defining trends within comparative folkloristics during the twentieth century. Such endeavors resulted in many seminal works which accumulate and interpret various themes and heroes, systemize and describe thousands of narrative motifs and their variants from around the world. Yet, any survey, index or directory could not be considered complete or comprehensive while accumulation of newly discovered materials from various oral traditions is ongoing ceaselessly, enriching the existing collections with formerly unknown data. 
This article seeks to involve into comparative folkloristics the new data found in oral tradition of the Muong, one of the minority groups in Vietnam. In particular, it examines some archetypal patterns in the Muong epic cycle of 'The Birth of the Earth and Water', which seems to be a piece of folk art practically unknown and unexplored outside Vietnam. The most common epic themes, such as creation, man's origin and reproduction, acquisition of culture, and hero's deeds and fights will be revealed through a number of motifs represented in tales constituting the Muong epic cycle. Through a comparative analysis of these themes and motifs in global and regional perspectives it will expose, on the one hand, obvious parallels with their representations in the world folklore and, on the other hand, some specific variations and local links. To do this, apart from using the published versions of Muong epics, I will draw on data gained through my interviews with Muong respondents about the content and pragmatics of epic texts, carried out in Vietnamese provinces of Hòa Bình and Phú Thọ, as well as in Ba Vì district of Hanoi area.

The article consists of five sections. The first one summarizes basic information on the Muong and their epics. The second one briefly reviews some conceptual issues on thematic and motific analyses in relation to the Muong epic cycle as well as provides relevant information on 'heroes studies' in folkloristics and suggests the most convenient pattern for a short discussion on the Muong culture heroes. This will be followed by three sections that look more closely into the main themes found in the epic cycle of 'The Birth of the Earth and Water' and introduce several related motifs. The fifth section also provides a preliminary analysis of the main culture heroes. The conclusion sums up the major observations made during the discussion and outlines areas for further research.

\section{THE MUONG AND MUONG EPICS}

The Muong (Muòng) are an officially recognized minority people of Vietnam ${ }^{1}$ and the closest relatives and neighbors of the Vietnamese (Kinh or Viẹt), the majority ethnic group in the country. The Muong live in settlements scattered across upland areas of several provinces of northern Vietnam - Hòa Bình, Phú Thọ, Sơn La, Thanh Hóa, as well as in Hanoi area (district of Ba Vì) and in the province of Nghệ An in the northern part of central Vietnam. According to the modern classification, the Muong and the Vietnamese together constitute the Viet-Muong sub-group of Vietic peoples and their common origin and cultural affinity is now persistently underlined in Vietnam. Vietnamese scholarly discourse claims that in ancient times ancestors of the Vietnamese and the Muong together constituted a community of the so called 'ancient Viets' (nguoòi Việt cổ). 
Yet, until the 1970s perception of the Muong and their culture had suffered from a specific attitude rooted in pre-colonial times. In the past, when the population of Vietnam did not see itself in ethnic categories, Muòng was a term that was used by Vietnamese elite in the lowlands, i.e., by Kinh people (literally 'capital inhabitants'), ${ }^{2}$ to refer to their immediate neighbors living in small villages to the west, upstream, in the hills and foothill areas. Since Viet-Muong speakers lived there intermingled with some Tai-speaking groups ${ }^{3}$, this term was historically used to designate linguistically diverse population.

Muòng is a Tai word (เมือง) meaning 'chiefdom', 'community', 'village' or 'country'. There is also a compound Muòng Mán (茫蠻) that is found in Vietnamese texts written in vernacular character script (Nôm), where Mán (蠻) appears to be the same Tai word with the same meaning but in its Han-Viet form. Initially this term was used by Chinese authors as a generic term to refer to all 'southern barbarians'. It is quite clear that the term Muòng and compound Muòng Mán were also used by the Vietnamese sinicized elite to designate 'uncivilized savages', 'mountain barbarians' without any ethnic connotation.

The emergence of the idea of 'the Muong people' as a separate ethnic group, according to Taylor, occurred in the 1920s when the term Muòng became, due to French colonial reasoning, a category to designate upland people linguistically related to the Vietnamese, or Kinh people, who were living in the lowlands (Taylor 2001). Being accepted as an official name of a minority group, the term Muòng appears to be merely an exonym since it is not used by the Muong to refer to themselves. The Muong use this term only to designate a territorial unit (a group of several settlements) or, by extension, each of the four spaces in three-level universe, according to their cosmological conception. ${ }^{4}$ Their autonym is 'Mol/Monl/Moan' (depending on the dialect), which is a Mon-Khmer ${ }^{5}$ word meaning 'people'.

Today the Muong continue to practice their traditional animist beliefs. They worship ancestral spirits, supernatural deities as well as spirits of some inanimate objects. The Muong concept of the soul, or rather numerous souls, inherent in humans and all physical beings, seems to be very sophisticated. A significant number of rituals, shamanistic by nature, are associated with this concept. Muong cosmological and religious ideas are widely represented in their ritual narratives, including tales from the epic cycle of 'The Birth of the Earth and Water'.

What is considered to be Muong epics has not attracted considerable attention in Western scholarship so far, although several tales were mentioned in descriptions of Muong funeral rites or partially retold in a few works published on the Muong and their culture (Grossin 1926; Cuisinier 1946). In Vietnam, Muong epics, as a whole cycle and a precious heritage of intangible culture, were 
discovered in the 1970s. By that time Vietnamese scholars, some of whom were ethnic Muong, had collected a significant amount of ritual narratives (Mo in Muong $)^{6}$ and had written them down in Vietnamese and also in Muong, using Vietnamese Latinized script. ${ }^{7}$ During textual analysis of collected materials scholars recognized that a certain group of tales that were recorded during mourning rituals appeared as an organic whole and looked very similar to what is commonly considered as epics. This body of tales was identified in Vietnamese as sư thi (literally, narrative verses) or truòng ca (long song), which are two terms corresponding to the European notion of epics. The opening episode (or two episodes in Thanh Hóa version) gave the title to the whole cycle - 'The Birth of the Earth and Water'. In the 1980s and 1990s Vietnamese (ĐĐĐN 1988, see Introduction by Đặng Văn Lung; Trương Sĩ Hùng 1992) and Russian (Nikulin 1985; 1996) scholars undertook the first attempts of analytical approach to Muong epics.

Tales of the epic cycle of 'The Birth of the Earth and Water' are referred to as Mo Tlêu in Muong, i.e., 'telling stories', and performed only during elaborate and lavish funerals. Unlike other Muong ritual narratives (for instance, Mo $V a i i$ 'Going back to ancestors') these tales have a certain sequence and share common heroes. They combine characteristics of both cosmological and heroic epics, narrate the origins of the world, animals and plants, the first people and their cultural practices, rulers and their deeds.

Narratives from the epic cycle are performed during nighttime, inside the Muong stilt house, with a large amount of relatives and villagers gathered around the coffin of the deceased. Recitation of epic tales is usually accompanied by a group of musicians with traditional instruments, while a Mo master could be assisted by one or two other ritual specialists. The purpose of such a performance consists in guiding the deceased's soul to the otherworld; at the same time, it is a good occasion to pass on elements of traditional culture and historical memories to younger generations. Unlike other Muong rituals, outsiders are not always welcome to attend these recitations.

Since the Muong language is unwritten, tales from the epic cycle of 'The Birth of the Earth and Water' as well as all other Muong ritual narratives have been passed down orally up to now. ${ }^{8}$ They have been transmitted mostly within families of ritual masters bố (thầy or ông) Mo who are, at the same time, professional storytellers. Tales are memorized in a certain sequence and then recited in a singing voice during lengthy funeral rites. ${ }^{9}$ The teller would, meanwhile, improvise on familiar material by drawing on a set of fixed themes, motifs, formulas, and metrical patterns, which has resulted in the appearance of a variety of epic versions spread throughout all the areas of Muong residence in northern Vietnam. To date, there are more than a dozen epic versions from 
three provinces of northern Vietnam (Hòa Bình, Thanh Hóa, Sơn La), which have been collected and published. ${ }^{10}$ The volume of poetry in these versions varies from three and a half to sixteen thousand lines, while a medium-volume version has about eight thousand lines. The collected versions slightly differ in the main characters' names, by focusing on one particular theme or another, but, generally, all of them follow a common narrative outline and share common motifs. Further in the article I will primarily draw on the earliest recorded version from the province of Hòa Bình, compiled in prose by Nguyễn Từ Chi and Nguyễn Trần Đản (ĐĐĐN 1974), referring to other versions of the epics in the case of divergences.

It remains unclear when the Muong epic cycle was created and how it evolved throughout time. The Muong authors themselves assume that the main body of epic tales could be compiled not later than the fifteenth century. According to them, this assumption is supported by genealogies of ritual masters' families, which can be traced from the end of the fifteenth century (Bùi Huy Vọng 2010: 29). Although this argument itself is not solid enough to be evidence indicating the time when the Muong epics were formed, I believe that this could well be so for two other reasons. Firstly, at the same time another part of the Viet-Muong population in the lowlands, i.e., the Kinh people, or ancestors of the modernday ethnic Vietnamese, were also creating, or at least recording, their own folk tradition. A larger part of this tradition is represented in one of the first collections of Vietnamese myths and legends entitled 'A Selection of Wondrous Tales of Linh Nam' (Lĩnh Nam chích quái liệt truyện), which demonstrates certain, though not always obvious at first glance, connections with themes and motifs found in the Moung epics. Secondly, since the Muong epic cycle, its motifs, concepts, and performing standards have much in common with Tai (or Thái as it precisely termed in Vietnam) religious and oral traditions, it might be formed in the time when the interaction between Taic and Viet-Muong people was quite intensive. As was noted by Kelley, the fifteenth century was just the time when the Lê dynasty, recently established in Vietnam (Đại Việt in that time), expanded its control into territories inhabited by Tai-speaking groups, to the west from Viet-Muong speaking areas (Kelley 2015: 182).

\section{CONCEPTUAL FRAMEWORK}

Thematic analysis is one of the useful tools for the interpretation of spoken or written narratives. In a general sense, it is applied to reveal what content a certain narrative communicates and how it is structured. Motific approach, in its turn, allows uncovering the way that the themes are represented. According to 
Daemmrich, "[t]hemes and motifs are basic components of literary works. Their arrangement, distribution, repetition, and variation form an intricate system of relationships which is an integral part of the textual structure" (Daemmrich 1985: 573). Both themes and motifs also provide a basis for identification, documentation, classification, and comparative studies of various narratives. This field of research seems to be well developed in folkloristics: in Dundes' words, "the identification of folk narratives through motif and/or tale type numbers has become an international sine qua non among bona fide folklorists" (Dundes 1997: 95).

However, there are a number of problems about thematic analysis that should be raised. Firstly, the meaning of the two terms - themes and motifs appears ambiguous in many contexts. Secondly, they are frequently, mainly in literature studies, employed interchangeably. For the sake of conceptual accuracy, it is worth to define these terms regarding the purposes of further analysis.

Themes are understood as fundamental ideas explored in a text. In folk narratives they are often universal by their nature and convey the most general ideas. Further I will discuss some of the standard epic themes, such as the creation of the universe, man's origin and reproduction, the acquisition of cultural practices, exploits of the main heroes as they are represented in the Muong epic cycle. The discussion will unfold through a number of appropriate motifs.

Motifs in narrative studies are generally defined as recurring elements with a symbolic meaning, which are used to expose and develop the major themes of the texts. According to Thompson, they are "those details out of which fullfledged narratives are composed" (Thompson 1955-1958: 10). Being memorable and easily repeatable patterns, motifs through repetition can vary and produce other themes or narratives as well as be reproduced in other forms of folk culture (song lore, imitative arts, etc.). Although the understanding of the term 'motif' differs from one scholar to another, ${ }^{11}$ the motific approach remains one of the main methods in the field of folk narratives documentation and comparative folkloristics. It is also widely used for introducing new texts.

In the Muong epic cycle motifs are easily identifiable since the cycle represents a sequence of clearly delineated and untitled tales, every one of which is marked by a new rằng, i.e. 'saying that'. The number and sequence of tales vary from one version of the epic cycle to another but, as a rule, a certain set of tales is included in all versions of the cycle: the birth of the Earth and Water, the birth of months and days, the birth of the sacred egg, asking for the fire, planting mulberry trees and breeding silkworms, building a house, matchmaking, the birth of the buffalo, the birth of the hen, water rising and drying up, the birth of rice, the birth of 'tube wine' (ruoou cần $)^{12}$, the birth of the 
bronze drum, the birth of the bowl, fighting an enemy, cutting the tree of Chu, burning the ruler's palace, hunting the monster. ${ }^{13}$ As can be seen, the larger part of the listed titles correlates with the motifs which are mentioned in section A of Thompson's Motif-Index and called 'Mythological motifs' (Thompson 1955-1958). Such an abundance of mythological motifs in the Muong epic cycle has given grounds for some scholars to consider the cycle as a variety of epic mythology. Thus, Nikulin identifies Muong epic tales as a 'mytho-epic cycle' (Nikulin 1985, 1996) while Trương Sĩ Hùng calls them 'mythic epics' (sủ thi thần thoại, Trương Sĩ Hùng 1992).

Thompson defines mythological motifs as those "having to do with creation and with the nature of the world: creators, gods, and demigods; the creation and nature of the universe, and especially of the earth; the beginnings of life; the creation and establishment of the animal and vegetable world" (Thompson 1955-1958: 20). In short, mythological motifs are the ones with 'explanatory' or 'etiological' quality, and motifs of the Muong epic cycle certainly match this category. At the same time, the peculiarity of Muong mythological motifs consists in the fact that they do not narrate stories about gods or supernatural creators since the process of creation and acquisition of culture occurs, according to Muong epics, due to the very nature or with participation of the first people and culture heroes, all of whom appear to be fairly earthly beings. Such a situation is typical of oral tradition of many peoples in Southeast Asia, whose worldview is widely influenced by animistic beliefs. Whereas there is no any specialized motif-index of Southeast Asian folklore, in further discussion I will refer to Thompson's classification despite the fact that not all motifs of Muong epics are represented there.

Whereas the Muong epic cycle seems to be more mythological (etiological by nature) rather than heroic, the analysis of its main culture heroes might provide a better understanding of this valuable piece of folk culture in its whole context. A typical culture hero, as this category is understood in folkloristics, might be represented as a creator-demiurge, redeemer and benefactor, as well as a discoverer of cultural practices, traditions or religion. He (or she, hardly ever) achieves great deeds on behalf of his people, tribe or civilization, and very often turns out to be the founder of the first ruling dynasty. Two characters depicted in Muong epic tales, namely, the ruler Tá Cần and especially King Dit Dàng, clearly meet the cited criteria. Yet, a notable feature of these personages is that they do not participate in the creation process as they appear on the stage when the universe and main natural phenomena have already been formed. Their main function is solely focused on the acquisition of cultural practices and establishing of social order. In this way, they act as creators of the real world adapted for human life. 
The so-called 'hero studies' were actively developing during the twentieth century and resulted in a number of seminal works among which the following are worth mentioning: 'Myth of the Birth of the Hero' by Otto Rank (Rank 1990 [1909]), 'The Hero: A Study in Tradition, Myth and Dreams' by Lord Raglan (Raglan 1990 [1936]) as well as Joseph Campbell's 'The Hero with a Thousand Faces' (Campbell 2004 [1949]). While the 'hero's journey' archetype outlined by Campbell (departure - initiation - return) is not well represented in Muong epics, the applying of the so-called 'hero pattern' initially elaborated by Rank and then developed by Raglan appears to be more appropriate for a short discussion on main culture heroes found in the Muong epic cycle.

\section{CREATION OF THE UNIVERSE: MOTIF OF GREAT DELUGE. MOTIF OF TREE OF LIFE}

In the opening part of the Muong epic cycle there is a 'rằng', i.e. a tale, or two 'rằng', depending on the version, talking about the origins of the Earth and the Water 'in the times when there is not yet the Earth down on the earth and there is not yet the Sky up in the sky':

That was a long time ago ... So long ago that it is impossible now to count years or months. There were neither years nor months then. Years and months had not existed yet... There were no seasons. There were neither days nor nights. There was no sun, nor moon, there were no stars. The sky and the earth were merged into a single mass then. (ĐĐĐN 1974: 5)

As in many other Muong stories, here one can find a mention of a drought that precedes the big rain:

...That was a time of terrible drought. The drought lasted very long. The sky and the earth were thrown into turmoil. (ĐĐĐN 1974: 6)

...Suddenly, heavy black clouds rolled out from nowhere. Impenetrable. Scary. Thunder rumbled loudly and wind roared all around. Lightning struck down and split the sky out of the earth. It was pouring with rain. Endlessly, without stopping. Small drops of the rain were as fruits of a ficus and large drops were as fruits of a giant fig. Wind was mixed with rain, rain filled the wind, the wind and rain were swirled in a terrible vortex.

Wind gusts filled the sky with air and raised it up. Rainwater softened the ground, but kept flowing with unusual force, turning into streams and flooding all around. The water had risen and stayed, separating the 
sky from the earth. Thus, the sky, the earth, and the water had appeared. (ĐĐĐN 1974: 7)

The motif of the great deluge or the flood myth is a very common pattern in worldwide folklore (Motif A1010 'Deluge. Inundation of whole world or section' in Thompson's Motif-Index). Its common meaning is to mark a new beginning after a great catastrophe, usually sent by deities. It is often an act of divine retribution that destroys the previous order. However, in Muong epics one can find a slightly different situation: the flood does not seem to be a kind of punishment or retribution. It is just the beginning of time since before the flood there was nothing in the world. In addition, it is worth mentioning that droughts alternating with rains can be attributed to specific features of Southeast Asian climate which is strongly influenced by monsoons. According to the Muong lunar calendar, the New Year, which is associated with spring and the beginning of a new life, also always falls on the end of the dry season turning into the season of big rains. On the whole, the motif of the great flood, which precedes the formation of the Universe and origin of mankind, is a very typical pattern in the Southeast Asian folklore (see Oppenheimer 1998; Stratanovich 1977).

A big rain after a terrible drought and a flood caused by it created the Universe. However, the earth was still uninhabited. In Muong epics the origin of mankind is connected with two other widespread motifs: the motif of tree of life and the motif of origin from eggs. Let us focus first on the motif of tree of life as it is represented in the Muong epic cycle and rituals.

Benjamin ficus tree, Cây Si in Muong, is considered to be a symbol of human life in Muong spiritual tradition. The Muong believe that everyone's soul is connected with a symbolic $S i$ tree planted in the sky. When trees of $S i$ are lush and green, the people who are connected with them are strong and healthy, but when the trees lose their leaves and dry, people become ill and die (cf. E760 'Object or animal has mystic connection with person. Changes in one correspond to changes in the other' in Thompson's Motif-Index). There is a special ritual termed 'pulling the $S i$ ' (Lế kéo $S i$ ) which appears to be similar to 'soul pulling' or 'soul retrieval' rituals in shamanistic traditions of other peoples in the world, and the purpose of which is to strengthen forces of the elderly, ill or weak people. ${ }^{14}$

The motif of tree of $\mathrm{Si}$, as it is depicted in Muong epics, also correlates with Thompson's E761.3.4. 'Life token: trees prostrate themselves', since miraculous emergence, unusual growth, and subsequent prostration of the tree had caused many transformations in the world. Thus, its big and small branches had transformed into Muong villages and settlements; when the tree toppled down, its fallen leaves became birds (symbol of the upper world in Muong culture) while its roots, drowned in the water, turned into fishes (symbol of the 
lower world and water realm); the stump of the tree ${ }^{15}$ gave birth to a pair of birds-progenitors. ${ }^{16}$

\section{MAN'S ORIGIN AND REPRODUCTION: MOTIF OF ORIGIN FROM EGGS. MOTIF OF INCEST}

The Muong story of descent links the origin of the first people (of the Muong as well as of some other neighboring peoples, such as the Kinh, i.e., ethnic Vietnamese, the Lao, the Thai, the Man, and the Meo) with eggs laid by a pair of birds Chim Ây and Cái Ú' $a^{17}$, which flew out of the ruined tree of Si. While all of a thousand (or sometimes ten thousand) first cracked eggs gave birth to various animals and other peoples, the last egg (or sometimes three last eggs) contained two brothers and a sister who became ancestors of the Muong. In Hòa Bình versions of the epic cycle the last egg is often named Điếng (ĐĐĐN 1976; Mo Mường Hòa Bình 2011) and it usually possesses certain distinctive features, to the point that it can even take the form of a square ( ĐĐÐN 1974).

The motif of origin from egg/eggs (A1222 'Mankind originates from eggs', according to Thompson's Motif-Index classification) is not only specific to the Muong epics but also represented in oral tradition of some other peoples in Asian and Pacific region (Stratanovich 1977: 62-73). Likewise, this motif seems to be echoed in the Vietnamese story of descent which narrates how the first Vietnamese appeared from one hundred eggs found in a sack born from the Father-Dragon and Mother-Fairy. ${ }^{18}$

In archaic mythology the first emerged heroes, either gods or mortals, are frequently depicted at once as brother and sister as well as husband and wife (cf. Zeus and Hera in Greek mythology, Chinese Fu Xi and $\mathrm{Nu} \mathrm{Wa,} \mathrm{and} \mathrm{so} \mathrm{on).}$ As they are the only two human beings in the world or very few within a newly emerged community, they marry among themselves to continue their race. Incest between gods or demigods is classified under section A 'Mythological Motifs' (A1273.1. 'Incestuous first parents') in the Thompson's Motif-Index, while incest between mortals occurs in section T 'Sex', within subsection T400 'Illicit Sexual Relations'. As the Muong progenitors are not considered to be gods or deities, I believe that the motif T415 'Brother-sister incest' seems to be more appropriate for analyzing Muong epics.

The motif of sibling incest along with the motif of the great deluge is a very specific pattern in Southeast Asian creation myths (Stratanovich 1977). It has two main versions: 1) brother and sister are the sole survivors of a flood; 2) two brothers and a sister appear in some miraculous way after a flood; the elder brother in the course of a certain testing turns to be unable to govern and/or 
to continue the human race; then the younger brother becomes the ruler and marries the sister to give birth to their offspring.

In Muong epics this motif is linked with the motif of the great deluge through origin from eggs: the first Muong people that hatched from the last/squared egg (or from three last eggs) are two brothers and a sister - Tá Cần, Tá Kài and cô nàng Kịt. The younger brother then becomes the first Muong ruler, Lang Tá Cần. After a twice-failed attempt of marriage (with the daughter of the king of the sky and with the daughter of the king of the underwater realm) the ruler Tá Cần marries his sister (nàng Kịt):

...that was a time when no one knew the Law of the Heaven. But as they had violated the Heaven's Law therefore the Heaven must punish them. (ĐĐĐN 1974: 36)

As a result of the Heaven's wrath, all the children born from this family pair are physically disabled - without arms, without legs, dumb, or deaf. Then one wise old man teaches the parents how to remedy the situation:

The Law of the Heaven does not allow brothers and sisters to marry among themselves. Only chickens and pigs can have such promiscuous relations. Both of you are the first people who were born from the squared egg, you are a brother and a sister, you should not be a husband and a wife. But, well, it has already happened; I have to find the way to correct it somehow. Now you have to leave each other. Let the man go to the east, and the woman go to the west. When you come back and meet each other, you have to pretend that you are not intimate, that you have never known each other. When you will be eating, the woman should eat in a shelter for chickens and the man in a pen for pigs, as if you are no different from animals. Then you have to have the wedding ceremony, with matchmaking rituals, according to the rules ... Maybe then you will be able to avoid the punishment of the Heaven. (ibid.)

Obviously, the motif of incest between the first parents is used in the context of Muong epics not only to narrate the way of ancestors' multiplying but also to taboo incestuous marriage and introduce norms of marital relations. The sibling incest committed by progenitors seems to be punished for but not strictly condemned. Such a representation supports the assumption made by Meletinskii concerning the ambivalence of the motif of incest in folklore: being aimed to eliminate incestuous relationship incest, per se, does not appear to be reproved since it is attributed to creation and considered to be inevitable (Meletinskii 1984). 
The motif of incest is not implicitly represented in the Vietnamese origin myth which was to a great extent rooted in Chinese written sources (Kelley 2012) and strongly influenced by Confucian ethics. However, some traces of the common Viet-Muong oral tradition are found in the Vietnamese story of descent as well: the Father-Dragon and Mother-Fairy also have to separate and go to opposite directions for some ambiguous reasons. In the Vietnamese story the spouses' separation is explained by the opposition of yin (âm) and yang (duong) which, on the one hand, is needed for producing offspring but, on the other hand, hinders a long cohabitation (Lĩnh Nam Chích Quái 2001: 31-32). As appealing to the Daoist categories of yin and yang sounds so vague and unconvincing in such a context, I believe that this association could be used in the Vietnamese story of descent to veil the previous connection with the motif of incest between progenitors, which was specific to the common Viet-Muong tradition.

\section{ACQUISITION OF CULTURE. THE MAIN CULTURE HEROES}

Motifs narrating the acquisition of culture constitute a significant part of Muong epics. They comprise some widespread motifs such as asking for fire (A1414 'Origin of fire'), acquisition of a house (variant of the A1402 'The gods build houses...'), livestock (buffalo, hen, pig - A1422 'Assignment of edible animals'), rice (A1423.2 'Acquisition of rice'), fermented rice wine (ruọu cần; A1427 'Acquisition of spirituous liquors'), metals (A1432 'Acquisition of metals') and ornaments (A1465.3 'Origin of ornaments'). In addition to that, the Muong epic cycle also contains several motifs that are not found in the existent motif-indexes. Such motifs, specific to the cultural area of Southeast Asia and Southern China, include motifs of the acquisition of sericulture, origin of the bronze drum (a ritual instrument used during funerals and a symbol of the ruler's authority), and the origin of the bowl.

Since there are no gods in the world of Muong epics, the acquisition of culture is performed by the first rulers - Tá Cần or his son, King Dịt Dàng, ${ }^{19}$ who appear to be two culture heroes. In the process of acquiring the elements of culture, they are assisted by numerous helpers or mentors, represented by a variety of living creatures or objects of nature. Thus, to obtain fire, the ruler Tá Cần first asks 'uncle Bat' (bác Gioi) ${ }^{20}$ to bring fire from the sky down to the earth (literally, 'from the realm of the sky down to the realm of people'). When Bat fails to bring fire to people (because an evil spirit has spilled water on the burning coals to extinguish the fire), the ruler asks 'uncle Horse-fly' (bác Ruồi trâu, literally 'Buffalo-fly') to do this. Although coals obtained in the sky the second time have again been sprinkled with water, the horse-fly has managed 
to deceive the master of fire, snoop on the way of making fire in the sky and convey it to people: to have fire, one needs to rub two bamboo sticks against each other near dry tinder made of split bamboo. Thereby, people have acquired fire to prepare their food while the horse-fly has merited the right to bite buffaloes and bulls in their back, bite people carrying yokes on their shoulders, and also bite beautiful young girls in different parts of their gentle body (ĐĐĐN 1974: 20-23).

Thus, like in many other world mythologies, in the Muong epic tales fire is obtained in a dishonest way (cf. the myth of Prometheus or some myths of Native Americans and peoples of the Amazon River basin). Characteristically, in Muong epics the theft of fire is also, as incest, not punished; on the contrary, the horse-fly who stole the fire and transmitted it to humans, gets rewarded even though such a reward seems to be merely an excuse for unpleasant actions produced by this animal creature. I believe that such interpretation is used by animism believers to emphasize nature's harmony and interrelationship between humans and the entire natural world.

To acquire every element of culture, the hero normally has to make two or three attempts. According to Muong epics, nothing is given to people on the first try. An example of this would be the motif narrating the acquisition of a house. It tells that the tortoise that was caught and then released by the ruler Tá Cần taught people a way of building houses: a house has to be similar to the tortoise's body - four main pillars are the tortoise's four paws; the ridge beam is its spine; lathing is its ribs; the front door is the tortoise's mouth, while the back door is its anus; trunks of wild sugarcane should be used to make minor pillars and bast of rattan stems to bind them together. The ruler Tá Cần and his people did exactly what the tortoise said but the first built house collapsed. Then the ruler Tá Cần caught the tortoise again and asked for explanations. The tortoise specified some details: the main pillars have to be made of ironwood and beams of wood of melia or dracontomelon. ${ }^{21}$ Bast for binding has to be made from aganonerion ${ }^{22}$, while the roof should be covered with straw (ĐĐĐN 1974: 23-26).

The acquisition of sericulture and silk weaving (in those epic variants where this motif is found ${ }^{23}$ ) is associated with women. In the Hòa Bình version of the epic cycle it is nàng Kịt, the ruler Tá Cần's sister and wife, who is involved in the process of acquiring silk. She had already learned to cultivate mulberry trees (it had been found out that trees should be planted in the fifth lunar month), but she had no silkworms yet. Nàng Kịt had to go very far across high mountains and deep rivers to meet $B a ̀$ Dit Bà Măm, a lonely old woman who was living in a dense forest (it is unclear whether this woman was a human or a spirit) and ask for silkworms. After that, Muong girls and women learned to breed 
silkworms, make silk thread, and produce cloth to sew clothes. Since then the Muong people had no need to wear loincloths made of liana and cover themselves with blankets made of tree bark (ĐĐĐN 1974: 26-28). In the variant of the epic cycle recorded in Son La province, the acquisition of silk is associated with Bì Dịt Dàng, wife of the king $D i ̣ t$ dàng, whereas narrating of the tale follows nearly the same template as in Hòa Bình variant of the epic (ĐĐĐN 2005: 291-298).

The motifs of acquisition of metals and ornaments, as they are represented in the Hòa Bình and Sơn La versions of the epic cycle, are connected with the king Dịt Dàng and his deeds. The king Dịt Dàng, the youngest of the children born from the first Muong parents (the ruler Tá Cần and nàng Kitt, his sister and wife), appears to be the main culture hero. It is remarkable that some Vietnamese scholars believe that the name Dit Dang (sometimes Yịt Yàng) is a Muong pronunciation of the term Việt Vuong, meaning 'the king of the Viet' (Nguyễn Từ Chi 1997: 131). This assumption is supported by available details of the king's life story: unlike his brothers and sisters who scattered all over the uplands to manage the settlements, Dit Dàng went down to the plains and became the king in the area of Kinh Ky Ké Cho , i.e. in the capital city with a market place, that is to say, in the area of the Kinh (or Viet) people in modern categories.

Characteristically, in the version of epics from Thanh Hóa, which is a province more remote from the capital city, modern Hanoi, the king Dịt Dàng receives far less attention as compared to the Hòa Bình and Sơn La variants of the epic cycle. Another interesting point is that some specific episodes narrating the Dit Dàng reign have obvious associations with the deeds committed by the Vietnamese culture hero - the Father-Dragon Lac Long Quân - as they are depicted in a fifteenth-century collection, 'A Selection of Wondrous Tales of Linh Nam' (Lĩnh Nam Chích Quái 2001). The revealed parallels will be discussed in more detail below. At the same time, some other very typical episodes have absolutely no association in Vietnamese tradition: Dịt Dàng's 'treachery', or rather ingratitude towards people from the uplands, the subsequent burning of his palace, and a military campaign of the uplanders against the king.

In the Hòa Bình and Son La variants of the epics, the deeds committed by the king $D i t$ Dàng include victorious battles, cutting down the tree of Chu with its 'bronze trunk, iron branches, brass flowers and tin fruits', building a palace and defeating an animal monster Tìn Vin Tuong Vuọng. Two of his deeds - defeating the monster and cutting down the tree - are reminiscent of the deeds of the Vietnamese culture hero, the Father-Dragon Lac Long Quân, as they are depicted in two stories from 'A Selection of Wondrous Tales of Linh Nam' - 'The story of the Fox essence' (Truyện Hò tinh) and 'The story of the Tree spirit' (Truyện Mộc tinh) (Lĩnh Nam Chích Quái 2001: 42-44, 57-60). While 
in Vietnamese stories the Father-Dragon merely saves people from malicious creatures and his deeds remain engraved in certain geographic sites around today's Hanoi, in Muong epic tales one would discover an explicit etiological context. Thus, the king Dịt Dàng not only defeated the monster Tìn Vìn Tuọng Vuọng and saved his people from trouble but also divided the monster's body into many parts. The Muong from different settlements as well as some neighboring peoples took different parts of the monster's body and carried them far away to their places of living to imitate drawings on the monster's skin. In such a way young girls and women have learned to weave and embroider different ornaments on the textiles they make (ĐĐĐN 1974: 94-100).

A victory over the animal monster is attributed mostly to the main culture hero only in the Hòa Bình and Sorn La versions of the epic cycle. According to Thanh Hóa variant of the Muong epics, this terrible beast was defeated collectively by people from different settlements led by their first rulers. ${ }^{24}$ Characteristically, the tale narrating the way of defeating the monster here is followed by another tale which tells about the extermination of two other malicious creatures - crazy fish (cá điên) and crazy crow (quạ điên) (ĐĐĐN 1975: 234244). Victories over all the three mentioned creatures - animal-monster, fish, and crow (bird) - once again appeal to the Muong conception of a three-level universe and its symbols. Extermination of the harmful creations of the upper world, earthly world, and lower world symbolizes control gained over the whole universe where, according to animistic beliefs, the seen world is interrelated to the unseen one. In the Vietnamese collection titled 'A Selection of Wondrous Tales of Linh Nam', in addition to the above-mentioned stories of Fox essence and Tree spirit, one can also find a tale depicting the victory gained by the Father-Dragon Lac Long Quân over the Fish essence (Ngu tinh) (Lĩnh Nam Chích Quái 2001: 39-41). In this way, in Vietnamese tradition the idea of three great deeds committed by progenitor(s), which is found in the Thanh Hóa variant of the epic cycle, is also represented; however, the emblematic association with the three-level structure of the universe seems to be lost.

Although the first king Dịt Dàng is depicted as a leader, civilizer, and savior of his people, even in the Hòa Bình and Sơn La variants of the Muong epics the 'hero cycle' does not appear to be well-developed. From twenty-two points outlined by Raglan for the typical 'hero pattern' (Raglan 1990 [1936]: 89-165) only eleven would hypothetically fit in the king Dịt Dàng life story (see Appendix 1). We are completely unaware of the king's children and continuation of the dynasty, his death, and posthumous veneration. Nearly nothing is said about the king's wife. Such a 'shortage' of the heroic content in Muong epics might be explained by the lack of political ambitions among the creators of the epics. Actually, we should keep in mind that ancestors of those people who 
are now referred to as the Muong have never had their own statehood in the uplands whilst political power has been always located in the lowlands (in the area of the capital city and the market place - Kinh Ky Kẻ Cho'), i.e. beyond their habitual landscapes, both natural and cultural.

\section{CONCLUDING REMARKS}

A brief overview of the Muong epic cycle of 'The Birth of the Earth and Water' clearly demonstrates that this epitome of oral creativity, practically unknown and unexplored in Western scholarship, represents a full-fledged product of the epic genre and appears to be well-deserved to take its place among the world's greatest epics. The tales constituting the cycle, their themes and motifs are deeply interrelated with animistic beliefs and cosmological ideas of the Muong people. As the Muong say themselves, Mo Tlêu, i.e. narratives of the epic cycle of 'The Birth of the Earth and Water', is a kind of unwritten encyclopedia of their life.

The tales of the cycle are compiled in the oral-formulaic tradition and intended for practicing long drawn-out mourning rituals. The time of creating of the epic cycle remains unclear but a number of indirect evidences allow assuming that it was developed no later than the fifteenth century.

As was shown, Muong epics narrate canonical epic themes, such as the creation of the universe, origin of mankind, acquisition of culture, mostly through a number of globally occurring motifs which are represented in Thompson's Motif-Index of Folk Literature (Thompson 1955-1958). They include the motif of the great deluge, motifs of the tree of life, origin from eggs, incest, acquiring of fire, rice, metals, building a house, and so on. Characteristically, none of these motifs in the Muong tales are associated with gods or deities as it occurs in most other epics or epic mythologies, but with various facets of local nature. Thus, according to Muong epics, the beginning of life is connected with heavy rain after severe drought and the huge ficus tree (the tree of $S i$ ) which embodies the idea of the tree of life in the Muong beliefs; fire is obtained in the sky by the horse-fly; the way of building a house is taught to people by the tortoise, and so forth. Obviously, this peculiarity of Muong epics is caused by an animistic worldview, assuming that humans are a part of the omnipotent nature and could be influenced by spirits of visible and invisible realms.

Along with worldly widespread motifs, Muong epic tales also comprise a number of motifs which are not found in Thompson's Motif-Index or in other motif inventories, and appear to be specific for the Southeast Asian culture area. They 
include motifs of acquiring the bronze drum, the bowl, acquiring sericulture and silk weaving.

Regarding the heroes represented in Muong epic tales, one should acknowledge that, unlike many other epics in the world, the cycle of 'The Birth of the Earth and Water' seems to be more mythological than heroic since it primarily focuses on giving accounts of the origins of various natural phenomena and core cultural practices rather than on depicting culture heroes, gods or the first rulers and their deeds. Actually, it appears to be more appropriate to consider this cycle as a variety of epic mythology rather than mere epics in the conventional sense of the term.

Although the tales constituting the Muong epic cycle and Vietnamese core myths and legends, as they are represented in the fifteenth-century 'Selection of Wondrous Tales of Linh Nam', were recorded five centuries apart and, at a glance, do not distinctively share common themes or heroes, an in-depth motific analysis reveals obvious parallels and interpretable divergences so that medieval Vietnamese mythology clearly appears as a more sinicized version of the Muong (or, evidently, formerly common Viet-Muong) narrative traditions. Thus, Vietnamese medieval myths and legends, explicitly or implicitly, echo a number of common Viet-Muong motifs, also found in the Muong epic cycle, such as origin from eggs, separation of progenitors as a punishment for the committed incest, overgrowth and subsequent destruction of the tree of life, defeating harmful creatures, such as an animal-monster (Fox essence in the Vietnamese case) or malicious fish. Characteristically, while all the motifs in Muong tales have evident etiological context and embody certain religious ideas, such as the conception of a three-level structure of the universe, for instance, in Vietnamese myths and legends the initial conceptual or etiological context seems to be blurred or reinterpreted.

Numerous parallels between the Muong and Tai (Thái) cultural practices, religious concepts, and narrative traditions revealed during the analysis might become a subject for further research.

In June 2015, ritual narratives of the Muong from the province of Hòa Bình, including tales from the epic cycle of 'The Birth of the Earth and Water', were awarded a certificate of special safeguarding by the Viet Nam National Commission for UNESCO. Obviously, in the coming years Vietnamese authorities will make all necessary efforts to have these narratives, together with traditions of their oral transmission and performance, recognized by UNESCO as world heritage. I believe that, compared to some other nominated culture objects and sites in Vietnam, Muong ritual narratives undeniably deserve this honor as they represent real oral heritage that brings to modern society cultural values and historical memories of previous generations. If this happens, the Muong 
epic cycle will become a part of the Intangible Cultural Heritage of Humanity along with some other Asian epics, such as Kyrgyz Manas, Yakut Olonkho, and Hudhud chants of the Ifugao people. Heritagization of the ritual narratives of the Muong people, including the cycle of 'The Birth of the Earth and Water' as their most essential component, will certainly contribute to further more detailed research into this cultural phenomenon and invaluable part of folk art. Hopefully, it will not seriously threaten the narratives as well as practices of their performance owing to standardization, decontextualization, and commercialization, which often accompany the process of heritagization.

\section{APPENDIX 1.}

\section{King Dịt Dàng as a culture hero}

(according to the Hòa Bình and Sơn La variants of the epic cycle)

\begin{tabular}{|c|c|c|c|}
\hline & $\begin{array}{l}\text { Twenty two points of the 'hero } \\
\text { pattern' according to Raglan }{ }^{25}\end{array}$ & Yes/No & Comments \\
\hline 1. & His mother is a royal virgin & $+(?)$ & $\begin{array}{l}\text { Nàng Kit, sister and wife } \\
\text { of the ruler Tá } C \text { ân; one of } \\
\text { the first people who were } \\
\text { born from eggs laid by } \\
\text { birds-progenitors }\end{array}$ \\
\hline 2. & His father is a king, and & + & $\begin{array}{l}\text { Ruler Tá Cần, one of the } \\
\text { first people who were born } \\
\text { from eggs laid by birds- } \\
\text { progenitors }\end{array}$ \\
\hline 3. & $\begin{array}{l}\text { often a near relative of his } \\
\text { mother, but }\end{array}$ & + & $\begin{array}{l}\text { His father and mother are } \\
\text { brother and sister }\end{array}$ \\
\hline 4. & $\begin{array}{l}\text { the circumstances of his } \\
\text { conception are unusual, and }\end{array}$ & + & $\begin{array}{l}\text { He was born from } \\
\text { incestuous marriage }\end{array}$ \\
\hline 5. & $\begin{array}{l}\text { he is also reputed to be the son of } \\
\text { a god. }\end{array}$ & - & $\begin{array}{l}\text { There are no gods in } \\
\text { Muong epics }\end{array}$ \\
\hline 6. & $\begin{array}{l}\text { At birth an attempt is made, often } \\
\text { by his father, to kill him, but }\end{array}$ & - & \\
\hline 7. & he is spirited away, and & - & \\
\hline 8. & $\begin{array}{l}\text { reared by foster parents in a } \\
\text { faraway country. }\end{array}$ & - & \\
\hline 9. & $\begin{array}{l}\text { We are told nothing of his } \\
\text { childhood, but }\end{array}$ & + & \\
\hline
\end{tabular}




\begin{tabular}{|c|c|c|c|}
\hline 10. & $\begin{array}{l}\text { when reaching manhood, he } \\
\text { returns or goes to his future } \\
\text { kingdom. }\end{array}$ & + & $\begin{array}{l}\text { He went down to the } \\
\text { plains and became king } \\
\text { in the area of Kinh } K \dot{y} K e \\
C h o, \text { i.e., in the capital } \\
\text { city with a market place }\end{array}$ \\
\hline 11. & $\begin{array}{l}\text { After a victory over the king and/ } \\
\text { or a giant, dragon, or wild beast, }\end{array}$ & + & $\begin{array}{l}\text { He defeated the monster } \\
\text { Tin Vin Tuong Vuong }\end{array}$ \\
\hline 12. & $\begin{array}{l}\text { he marries a princess, often the } \\
\text { daughter of his predecessor, and }\end{array}$ & - & $\begin{array}{l}\text { No data on his wife. } \\
\text { The only information } \\
\text { is, according to Son La } \\
\text { variant of the epic cycle, } \\
\text { that she contributed to the } \\
\text { acquisition of sericulture }\end{array}$ \\
\hline 13. & becomes king. & + & \\
\hline 14. & $\begin{array}{l}\text { For some time he reigns } \\
\text { uneventfully, and }\end{array}$ & + & \\
\hline 15. & prescribes laws, but & + & \\
\hline 16. & $\begin{array}{l}\text { later he loses favor with the gods } \\
\text { and/or his subjects, and }\end{array}$ & + & $\begin{array}{l}\text { His palace in the plains } \\
\text { was burnt by people from } \\
\text { the uplands }\end{array}$ \\
\hline 17. & $\begin{array}{l}\text { is dethroned and driven out of the } \\
\text { city. }\end{array}$ & - & \\
\hline 18. & $\begin{array}{l}\text { He meets with a mysterious } \\
\text { death, }\end{array}$ & - & $\begin{array}{l}\text { No information on his } \\
\text { death }\end{array}$ \\
\hline 19. & often at the top of a hill. & - & \\
\hline 20. & $\begin{array}{l}\text { His children, if any, do not } \\
\text { succeed him. }\end{array}$ & - & $\begin{array}{l}\text { No information on his } \\
\text { children }\end{array}$ \\
\hline 21. & $\begin{array}{l}\text { His body is not buried, but } \\
\text { nevertheless }\end{array}$ & - & \\
\hline \multirow[t]{2}{*}{22.} & $\begin{array}{l}\text { he has one or more holy } \\
\text { sepulchers. }\end{array}$ & - & \\
\hline & Total score & 11 & \\
\hline
\end{tabular}

\section{ACKNOWLEDGEMENTS}

This research was supported by the Russian Foundation for Humanities, project № 16-24-09001. 


\section{NOTES}

1 According to the 2009 Census, the Muong population in Vietnam amounted to about 1.3 million people (Census 2010: 134).

${ }^{2}$ Kinh is a Chinese borrowing, meaning 'capital city' or, by extension, 'capital inhabitants' (Chinese Jīng, 京).

3 Hereinafter the term 'Tai' is used as a general term to refer to the speakers of any Tai language in the Tai-Kadai (or Cra-Dai) language family. Actually, Vietnamese scholars make a distinction between 'Tày' (Central Tai) and 'Thái' (Southwestern Tai) languages and peoples. As today the Muong mostly live side by side with those Taispeakers who are named Thái, according to Vietnamese classification, I will sometimes employ this specific term to refer to this group.

4 According to Muong cosmological conception, the universe is composed of three worlds disposed along a vertical axis - the upper world (tloi), the flat world on the earth (pua bằng) and the underworld (pua tịn). While the upper world corresponds to the muong of the sky (muòng tloi or muòng kloì) and the flat world corresponds to the muong of people (muòng mol), the underworld is divided into two different muongs - the muong of spirits (muòng $\mathrm{ma}$ ) and the muong of the king of underwater (muòng púa khú). For more on this, see Nguyễn Từ Chi 1997.

5 Vietnamese and Muong languages constitute the Viet-Muong subgroup of the Vietic languages within the Mon-Khmer branch of the Austro-Asiatic language family.

6 Mo is a Tai word meaning ritual narratives, ritual recitations, and ritual specialists in Muong.

7 The so-called Muong language consists of a number of closely related dialects, all of which officially remain unwritten. Although the official implementation of a standardized writing system for the Muong language seems to be problematic because of significant language variations, practically all types of Muong texts can be recorded

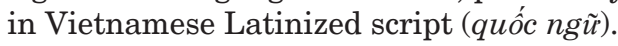

8 There is a story explaining why the Muong do not write down their tales but have to memorize them: Once the Muong were bringing characters back to their home but when they crossed a stream they put characters into the mouth and inadvertently swallowed them. Since then, when the Muong need to tell stories, they have to get scripts off from their entrails (ĐĐĐN 1988: 9). The last expression 'to get scripts off from their entrails' is associated with the starting moment of recitation when the ritual master is 'trying his voice' by producing sounds similar to a kind of throat singing.

A similar story is typical for some other peoples of northern Vietnam, which have no script for their languages.

9 To prevent a dead body from rotting and preserve it for lengthy funeral ceremonies (up to eighteen days in the past), the Muong would use some local herbs (information gained during fieldwork in 2015).

${ }^{10}$ For a survey of the published versions of Muong epics see Mo Mường Hòa Bình 2011, pp. 14-17. 
${ }^{11}$ Highlights of the motif in literature relevant for the current research include BenAmos 1980, 1995; Dundes 1962, 1997; Nekliudov 2004; Veselovskii 1989 [1940].

12 'Tube wine' (ruơu cần) is a fermented alcoholic beverage (up to 25\% alcohol) prepared of cooked glutinous rice. This beverage is consumed, often collectively, through long, thin cane tubes that are put into a jar.

${ }^{13}$ The cited list of tales is specific to the Hòa Bình version of Muong epics (ĐĐĐN 1976, for instance). In the Thanh Hóa variant, there are twenty-eight tales, some of which are titled a little bit differently: 'delineating years and months', 'looking for a pig, looking for a hen’, and so on (ĐĐĐN 1975).

${ }^{14}$ For more on this among the Muong see Bùi Huy Vọng 2015: 72-83; Đặng Văn Tu 1988; Phùng 2015.

${ }^{15}$ Nikulin has suggested that the famous Dong Son bronze drums, numerously found in northern Vietnam, could represent a symbolic stump of the Muong tree of life (Nikulin 1995, 1996). I do not find this convincing as I have never observed any associations of the tree of $S i$ with the bronze drum - neither in Muong rituals nor in oral tradition.

${ }^{16}$ Nikulin mentions that the scene of cutting the tree of $S i$ is found in the epic cycle 'The Birth of the Boundless' (Äm Êt Luông) of the Thái people in northern Vietnam (Nikulin 1996: 129-130). Unfortunately, so far I have had no possibility to compare the perception of the tree of $S i$ among the Thái and the Muong.

${ }^{17}$ In the Thanh Hóa variant of epics the birds are named Tùng (male) and Tót (female) trống chim Tùng, mái chim Tót (ĐĐĐN 1975).

${ }^{18}$ An appealing interpretation of the motif of origin from eggs was suggested by the Russian scholar Stratanovich. Analyzing two main patterns of descent typical of the oral tradition in Southeast Asia (descent from egg/eggs or descent from gourd), Stratanovich suggested that the motif of origin from eggs might be an evidence of a 'second birth'. That is to say, according to Stratanovich, the pattern of descent from eggs, unlike the origin from gourd, could be a marker of a new cultural tradition that emerged due to migration, cultural contacts or assimilation of a former aboriginal group (Stratanovich 1977). While Stratanovich's assumption has not been thoroughly verified or confirmed by other folklorists or anthropologists, historical linguistics nevertheless testifies in favor of his theory: according to recent findings in the history of Viet-Muong languages, once (probably at the turn of the Common Era) the Viet-Muong speakers migrated to the area of what is now northern Vietnam from the mountain regions of eastern Laos and interacted here with Taic and other aboriginal peoples before being influenced by the Chinese (Nguyễn Tài Cẩn 1995).

${ }^{19}$ In the Thanh Hóa variant of Muong epics, Dịt Dàng is born from the first of twelve eggs laid by birds-progenitors, and therefore appears to be Tá Cần's brother. Here he is merely one of the first rulers (lang cun), along with several others, not the main culture hero as in the other versions of the epic cycle.

${ }^{20}$ According to modern spelling rules, the word 'bat' in Vietnamese should be written as Doi, not Gioi. 
${ }^{21}$ All these trees are valuable timber trees. Lim tree is Erythrophleum fordii, found in southeastern China, Taiwan, and Vietnam; Melia azedarach is a tree of Meliaceae family; Dracontomelon is a genus of flowering trees in the family Anacardiaceae; it is a common urban tree in Hanoi.

${ }^{22}$ Aganonerion polymorphum is a plant native to Indochina (Thailand, Laos, Cambodia, Vietnam), genus in the dogbane family Apocynaceae.

${ }^{23}$ The motif of acquisition of sericulture and silk weaving is not found in the Thanh Hóa variant of the Muong epics.

${ }^{24}$ Two terms, 'Cun' and 'Lang', or their combination, 'Lang Cun', are used in epic tales to designate the rulers' titles in the uplands settlements. The king Dịt Dàng's title in the Hòa Bình and Sơn La variants of the Muong epics is termed as vua/bua, i.e. 'the king'.

${ }^{25}$ Raglan 1990 [1936]: 89-165.

\section{REFERENCES}

Ben-Amos, Dan 1980. The Concept of Motif in Folklore. In: Venetia J. Newall (ed.) Folklore Studies in the Twentieth Century: Proceedings of the Centenary Conference of the Folklore Society. Woodbridge, UK: D.S. Brewer \& Totowa, NJ: Rowman and Littlefield, pp. 17-36.

Ben-Amos, Dan 1995. Are There Any Motifs in Folklore? In: Frank Trommler (ed.) Thematics Reconsidered: Essays in Honor of Horst S. Daemmrich. Amsterdam \& Atlanta: Rodopi, pp. 71-85.

Bùi Huy Vọng 2010. Tang Lễ Cổ Truyền Nguòi Muòng. [Muong Traditional Funeral Rites.] Hà Nội: NXB Đại Học Quốc Gia.

Bùi Huy Vọng 2015. Văn hóa dân gian Mưòng: Một góc nhìn. [Muong Folk Culture: A View.] Hà Nội: NXB Khoa Học Xã Hội.

Campbell, Joseph 2004 [1949]. The Hero with a Thousand Faces. Princeton: Princeton University Press.

Census $2010=$ The 2009 Vietnam Population and Housing Census: Completed Results. Hà Nội: The Central Population and Housing Census Steering Committee.

Cuisinier, Jeanne 1946. Les Muòng: géographie humaine et sociologie. Paris: Institut d'Ethnologie.

Daemmrich, Horst S. 1985. Themes and Motifs in Literature: Approaches - Trends Definition. The German Quarterly, Vol. 58, No. 4, pp. 566-575. http://dx.doi. org/10.2307/406945.

Đặng Văn Tu 1988. Cây si trong văn nghệ dân gian. [Benjamin Fig Tree in Folklore.] In: Nguyễn Từ Chi (ed.) Nguòi Muoòng vói văn hoá cổ truyền Muoòng Bi. [Muong People with Traditional Muong Bi Culture.] Hà Sơn Bình: UBND Huyện Tân Lạc, Sở VHTT, pp. 146-156.

ĐĐĐN 1974 = Đẻ Đất Đé Nưóc. Truyền thuyết dân tộc Muòng. [The Birth of the Earth and Water: Legends of the Muong People.] Nguyễn Từ Chi and Nguyễn Trần Đản. Hà Nội: NXB Kim Đồng. 
ĐĐĐN 1975 = Đẻ Đất Đẻ Nước. Sủ Thi dan tộc Muoòng. [The Birth of the Earth and Water: The Muong Epics.] Thanh Hóa: Ty Văn Hóa Thanh Hóa - Tiểu Ban Văn Nghệ Dân Gian.

ĐĐĐN 1976 = Đẻ Đất Đẻ Nưóc. Tho dân gian dan tộc Mưòng. [The Birth of the Earth and Water: The Muong Folk Poetry.] Hà Nội: NXB Văn Học.

ĐĐĐN 1988 = ĐéĐát Đé Nước. Sủ Thi Muòng. [The Birth of the Earth and Water: The Muong Epics.] Đặng Văn Lung, Vương Anh, Hoàng Anh Nhân. Hà Nội: NXB Khoa Học Xã Hội.

ĐĐĐN 2005 = Mo kể chuyện Đẻ Đất Đẻ Nuoóc (Song ngũ Muòng - Việt). [Mo-Master Is Telling Stories of the Birth of the Earth and Water (Parallel Texts in Muong and Vietnamese).] Đinh Văn Ân (Sưu tầm và dịch). Hà Nội: NXB Văn hóa dân tộc.

Dundes, Alan 1962. From Etic to Emic Units in the Structural Study of Folktales. The Journal of American Folklore, Vol. 75, No. 296, pp. 95-105. http://dx.doi. org/10.2307/538171.

Dundes, Alan 1997. The Motif-Index and the Tale Type Index: A Critique. Journal of Folklore Research, Vol. 34, No. 3, pp. 195-202. Available at https://www.jstor.org/ stable/3814885?seq=1\#page_scan_tab_contents, last accessed on 12 March 2019.

Grossin, Pierre 1926. La province Muong de Hoa-Binh. Hanoi: La Revue Indochinoise.

Kelley, Liam C. 2012. The Biography of the Hồng Bàng Clan as a Medieval Vietnamese Invented Tradition. Journal of Vietnamese Studies, Vol. 7, No. 2, pp. 87-130. DOI: $10.1525 / v s .2012 .7 .2 .87$.

Kelley, Liam C. 2015. Inventing Traditions in Fifteenth-Century Vietnam. In: V. Mair \& L. Kelley (eds.) Imperial China and Its Southern Neighbours. Singapore: Institute of Southeast Asian Studies, pp. 161-192.

Lĩnh Nam Chích Quái 2001 = Lĩnh Nam chích quái: truyện cổ dân gian suu tập biên soạn $o ̛$ thế $k \dot{y} X V$. [Selection of Wondrous Tales of Linh Nam: Folktales Collected and Compiled in the Fifteenth Century.] Compiled by Vũ Quỳnh \& Kiều Phú; edited by Đinh Gia Khánh. Hà Nội: Văn học.

Meletinskii, Eleazar 1984. Ob arkhetipe intsesta $\mathrm{v}$ fol'klornoi traditsii (osobenno v geroicheskom mife). [On the Archetype of Incest in Oral Tradition (Especially in Heroic Epos).] In: B. Putilov (ed.) Fol'klor i etnografiia: U etnograficheskikh istokov fol'klornykh siuzhetov i obrazov. [Folklore and Ethnography: At the Ethnographic Origins of Themes and Images in Folklore.] Leningrad: Nauka, pp. 57-62.

Mo Muòng Hòa Bình 2011. [Ritual Narratives of the Muong from the Province of Hòa Bình.] Hòa Bình: Ủy Ban Nhân dân Tỉnh Hòa Bình.

Nekliudov, Sergei 2004. Motiv i tekst. [Motif and Text.] In: S. Tolstaia (ed.) Iazyk kul'tury: Semantika i grammatika. [Language of Culture: Semantics and Grammar.] Moscow: Indrik, pp. 236-247. Available at http://inslav.ru/images/ stories/pdf/2004_Jazyk_kul\%27tury_semantika_i_grammatika.pdf, last accessed on 12 March 2019.

Nguyễn Tài Cẩn 1995. Giáo trình lịch sủ ngũu âm tiếng Việt (so thảo). [Textbook of Vietnamese Historical Phonology (Draft).] NXB Giáo dục.

Nguyễn Từ Chi 1997. La Cosmologie Muong. Paris: L'Harmattan. 
Nikulin, Nikolai 1985. Mifo-epicheskie skazaniia narodov V'etnama. [Myths and Epics of Vietnam.] In: S. Nekliudov (ed.) Spetsifika zhanrov v literaturakh Tsentral'noi $i$ Vostochnoi Azii. Couremennost'i klassicheskoe nasledie. [The Specifics of Genres in the Literatures of Central and Eastern Asia: Modernity and Classic Heritage.] Moscow: Nauka, pp. 7-38.

Nikulin, Nikolai 1995. V'eto-myongskii mif o mirovom dreve i stanovlenie literatury. [The Viet-Muongian Myth of the World Tree and the Formation of Literature.] In: E. Kotliar \& B. Riftin (eds.) Mifologiia i literatury Vostoka. [Mythology and Literatures of the Orient.] Moscow: Nasledie, pp. 126-147.

Nikulin, Nikolai 1996. Arkhaicheskii epos narodov V'etnama. [Archaic Epics of Vietnam.] In: N. Nikulin (ed.) Epos narodov Zarubezhnoi Azii i Afriki. [Epics of Foreign Countries of Asia and Africa.] Moscow: Nasledie, pp. 127-185.

Oppenheimer, Stephen 1998. Eden in the East: The Drowned Continent of Southeast Asia. London: Phoenix.

Phùng, Huyền Trang 2015. Cây Si trong đời sống tinh thần của người Mường. Báo Phú Tho diẹn tủ. [The Tree of $S i$ in the Spiritual Life of the Muong. Phú Thọ, Online Paper.] 21 March. Available at http://baophutho.vn/van-hoa/201503/cay-si-trongdoi-song-tinh-than-cua-nguoi-muong-130141, last accessed on 12 March 2019.

Raglan, Lord 1990 [1936]. The Hero: A Study in Tradition, Myth, and Drama. In: Robert Segal \& Alan Dundes \& Lord Raglan \& Otto Rank. In Quest of the Hero. Princeton: Princeton University Press, pp. 89-175.

Rank, Otto 1990 [1909 in German]. The Myth of the Birth of the Hero. In: Robert Segal \& Alan Dundes \& Lord Raglan \& Otto Rank. In Quest of the Hero. Princeton: Princeton University Press, pp. 2-87.

Stratanovich, Grigorij 1977. Etnogeneticheskie mify ob iskhode iz iaitsa ili tykvy u narodov Iugo-Vostochnoi Azii. [Ethnogenetic Myths on Origin from Egg or from Gourd among the Peoples of Southeast Asia.] In: R. Lipec (ed.) Etnicheskaia istoriia $i$ fol'klor. [Ethnic History and Folklore.] Moscow: Nauka, pp. 62-73.

Taylor, Keith 2001. On Being Muonged. Asian Ethnicity, Vol. 2, No. 1, pp. 25-34. http:// dx.doi.org/10.1080/14631360120017997.

Thompson, Stith 1955-1958. Motif-Index of Folk Literature: A Classification of Narrative Elements in Folktales, Ballads, Myths, Fables, Mediaeval Romances, Exempla, Fabliaux, Jest-Books, and Local Legends. Revised and enlarged edition. Bloomington: Indiana University Press. Available at https://sites.ualberta.ca/ urban/ Projects/English/Motif_Index.htm, last accessed on 7 March 2019.

Trương Sĩ Hùng 1992. Sủ Thi Thần Thoại Muoòng. [Muong Mythic Epics.] Hà Nội: NXB Văn hóa dân tộc - Viện Đông Nam Á.

Veselovskii, Alexander 1989 [1940]. Poetika siuzhetov. [Poetics of Plots.] In: A.N. Veselovski (comp.) Istoricheskaia poetika. [Historical Poetics.] Moscow: Vysshaia shkola, pp. 300-306. Available at http://biblio.imli.ru/images/abook/ teoriya/Veselovskij_A._N._Istoricheskaya_poetika._1989.pdf, last accessed on 12 March 2019. 